\title{
An Investigation of Attitudes of Employees From Different Age Groups (Generations) Towards Fun At Work, Experienced Fun At Workplace, Job Satisfaction, and Turnover Intention
}

\author{
Farklı Yaş Gruplarındaki (Kuşaklardaki) Çalışanların İş̧yerinde Eğlenmeye \\ Yönelik Tutumu, İşyerinde Eğlenme Düzeyi, İş Tatmini ve İşten \\ Ayrıllma Niyetine İlişsin Bir Araştırma
}

\author{
Prof. Dr. Işıl M. Pekdemir - Res. Asst. Selçuk Yeke - Asst. Prof. Dr. Murat Yaşlıoğlu
}

\begin{abstract}
This paper aims to present attitudes towards fun at work, experienced fun, job satisfaction and turnover intention of age generations; determine relations between attitudes towards entertainment at work, experienced fun, job satisfaction, and turnover intention. Also, another purpose of this research is to find differences between attitudes towards entertainment at work, experienced fun, job satisfaction, and turnover intention in terms of generations. Research was carried out at a manufacturing factory. Research data was obtained from 94 executives who work at the factory. A questionnaire was used to obtain data. According to results of research, attitudes towards entertainment at work directly affect turnover intention. Job satisfaction has mediating role on this effect. Also, it can be said that experienced fun has moderating role on direct and indirect relations between aforementioned variables.
\end{abstract}

Keywords: Generations, Fun At Work, Job Satisfaction, Turnover Intention

\section{Öz}

Bu çalışma işyerinde eğlenmeye yönelik tutumu, ĕglenme düzeyini, iş tatminini ve işten ayrlma niyetini ortaya koymak ve işyerinde eğlenmeye yönelik tutum, eğlenme düzeyi, iş tatmini ve işten ayrilma niyeti arasindaki ilişkileri belirlemek amacıyla gerçekleştirilmiştir. Ayrıca işyerinde eğlenmeye yönelik tutum, eğlenme düzeyi, iş tatmini ve işten ayrılma niyetinin kuşaklara göre farklilıklarını ortaya koymak çalışmanın diğer bir amacın oluşturmaktadır. Araştıma bir üretim işletmesinde gerçekleştirilmiştir. Üretim işletmesinde görev yapan 94 beyaz yakalı çalışandan veri toplanmıştır. Veri toplamak için anket yöntemi kullamılmıştır. Araştırmanın sonuçlarına göre, işyerinde eğlenmeye yönelik tutum işten ayrilma niyetini doğrudan etkilemektedir. Eğlenmeye yönelik tutumun işten ayrılma niyeti üzerindeki etkisinde iş tatmininin aracllik rolü ortaya çıkmıştır. Ayrıca eğlenme düzeyinin işyerinde eğlenmeye yönelik tutum, iş tatmini ve işten ayrlma niyeti arasındaki doğrudan ve dolayl ilişkilerinde moderator rolü ortaya çıkmıştır.

Anahtar Kelimeler: Kuşaklar, İşyerinde Eğlenme, İş Tatmini, İşten Ayrılma Niyeti

Prof. Dr. Işıl M. Pekdemir, Istanbul University Business Faculty, isilmp@istanbul.edu.tr Res. Asst. Selçuk Yeke, Istanbul University Business Faculty, selcuk.yeke@gmail.com Asst. Prof. Dr. Murat Yaşlıoglu, Istanbul University Business Faculty, muratyas@istanbul.edu.tr 


\section{Introduction}

It is natural to have differences in thinking and behavior between people who were born in different time periods. Companies try to bring their employees', who are different in terms of age, way of thinking and behaviors, together toward common goals in the same work environment and get higher efficiency. But time-to-time, difficulties may be experienced in old and young generations working together, there can be conflicts between the generations who are present in the same work environment and getting efficiency from both sides in this respect can become difficult. Companies, which want to benefit from the young generation's energy, ideas and creativity, are also in the position of directing old generation towards goals while benefiting from their experience and presenting appropriate working conditions towards the expectations of all employees. As there can be differences between people towards the expectation of work, which is one of the working conditions; as mentioned above, there can be differences between generations (Lamm and Meeks, 2009). Being affected by the time period they were born, some employees may want to work in a more serious atmosphere, while others want to work in a more cheerful and relaxing atmosphere and have fun (Ford, 2003). Differences between attitudes of employees towards fun at work can reveal differences between their experienced fun at work and in return can result in different levels of job satisfaction. Such that employees with high job satisfaction tend to work in their current workplaces, while others who do not have job satisfaction or have low job satisfaction can think about leaving their workplace (Karl et al., 2008). In this context, a research is planned to measure attitudes of people, who were born in different periods (generations), towards fun at workplace, level of experienced fun at workplace, job satisfaction and turnover intention. "Fun" topic is relatively new consideration for Turkish companies and especially as the members of generation Y started to take place in business life, importance given to having fun while working has become a growing paradigm. When it is considered that turnover intention is high in Turkey, it is observed that there is a gap to discover relation fun at work and turnover intention. As it is known that experienced fun have effect on job satisfaction, also it is considered to test relation between experienced fun and job satisfaction in this research. Also it is aimed to explore whether generations in Turkey gives similar importance to fun at work. This study gives an important detail that structure of industry and production can be a factor affecting attitude towards fun at work and experienced fun. Because structure of industry and production determines working conditions and work environment.

\section{Conceptual Framework}

\section{Generations}

Economic, social and technological circumstances of the era, affect perspectives of people towards life and work. Because of this, examining differences between perspectives, expectations and behaviors of people towards business life and consequences of these are discussed in various studies. While these studies specify generations according to different age groups, different ranges of time periods are used with slight differences. Strauss and Howe $(1991 ; 32)$ examined generations under five groups starting from the year of 1901; Greatest generation (1901-1924), Silent generation (1925-1942), Baby Boomer generation (1943-1960), generation X (1961-1981) and generation Y (1982 and later). And for people who were born after the year 1996, generation $\mathrm{Z}$ is to be mentioned (Montana and Petit, 2008; 140). There are also perspectives that accept people who were born in 2000s as the generation Z (Reeves and Oh, 2007; 297).

Greatest generation (1901-1924) consists of people with strong occupational identities. This generation, which is highly rational, gives importance to friendship and community spirit. Members to this generation are mostly highly optimistic. The Silent generation (1925-1942) has grown up in the times of Great Depression (1930) and the Second World War. The main traits of this generation are; tendency to be in control, being a pathfinder and a provider of communication and being helpful (Strauss and Howe, 1991). Generation $\mathrm{Z}$ is a generation, which is accustomed to digital world, and cannot acknowledge a life without internet. They can connect to the entire world through social media without the limitations of time and space (Levickaite, 2010; 172 - 173). In our study, as they take place in today's business life, Baby Boomer generation and generation $\mathrm{X}$ and $\mathrm{Y}$ are to be examined. Since generation $\mathrm{Z}$ is not taking an active role in business life, it will be impossible to measure their approach to any variable to be included. 


\section{Baby Boomer Generation}

People who were born between 1943 and 1960 (Strauss and Howe, 1991; 32), and according to another point of view, people who were born between 1946 and 1964 are acknowledged to be in the Baby Boomer generation (Macunovich, 2000; 1). This generation, which is also named to be the "Boomer generation" in Turkey; is a generation where the sense of longing for welfare, goods, and services is predominant (Ayhün, 2013; 99). Employees belonging to this generation consider hard working and altruism to be the most important factors in success (Tolbize, 2008; 3). This generation, which literally lives to work, respects authority and hierarchy in the workplace. This situation can be reasoned by the fact that they grew up in an environment that respects authority and hierarchy (Gursoy et al., 2008; 451). For employees of the Baby Boomer generation, business ethics is an important issue. This generation can spend most of their days working and does not complain about it, and if any extra effort besides the regular working hours is necessary, they usually accept this voluntarily (Sudheimer, 2009; 59). Baby Boomer generation has high energy and is the first generation that gives importance to marketing and product promotion in business (Macunovich, 2000; 4).

\section{Generation X}

Generation $\mathrm{X}$, according to one opinion, comprises people who were born between 1961 and 1981 (Strauss and Howe, 1991; 32), according to another opinion, generation $\mathrm{X}$ is accepted to be people who were born between 1960 and 1980 (Oppel, 2007; 1). And according to another opinion, people who were born between 1965 and 1979 constitute the generation X (Crampton and Hodge, 2009; 1). Generation X grew up in an environment where social changes occur rapidly and insecurity from the social aspect gains a seat (Cennamo, 2008; $892-893$ ). It is a generation that acts carefully and with delicacy. Main characteristics of this generation are giving importance to job and family and respectfully serving the institution where he/she works in (Strauss and Howe, 1991). This generation seeks a balance between family, work, and personal life (Kian and Yusoff, 2012; 397 - 398). Generation X, which has a positive look towards life, has a nature that is conservative, does not like risks and gives importance to ethical concepts (Susaeta et al., 2013; 324). Motivation of generation X in the business life is fairly low, and they mostly avoid competition (Sayers, 2007; 479 - 480). For this generation, achieving higher ranks in business life is not a priority; because time spent for this rivalry in business will reduce their quality of life and limit the time they spend with their family.

\section{Generation $Y$}

There are various opinions that consider generation $\mathrm{Y}$ to be people who were born in 1982 and later (Strauss and Howe, 1991; 32), to be inside the age range of 1980-1999 (Crampton and Hodge, 2009; 1) and that accepts generation $\mathrm{Y}$ to be people who were born between 1980 and 2002 (Oppel, 2007; 1). And according to another opinion, generation $\mathrm{Y}$ is considered to be people who were born between the years of 1978 and 1994 (Montana and Petit, 2008; 139). Generation Y uses technology more effectively compared to preceding generations. Compared to the elder generations, which grew up in times when technology's development speed was slow, generation $Y$ happens to be the one that is most affected by it (Deal et al., 2010; 192 - 193). Generation Y has always been in touch with the technology and has a higher education level on average. This establishes a foundation for them to question the activities that take place in contemporary business (Cairncross and Buultjens, 2007; 6).

The main characteristics of generation $\mathrm{Y}$ are; giving importance to the element of trust, improving themselves, being open to learning and having their own personal values (Strauss and Howe, 1991). Myers and Sadaghiani $(2010 ; 226)$ specified the traits that reflect generation $\mathrm{Y}$ to be: being social, having expectations towards development of relationships within the workplace, mastering in information and communication technologies, focusing on success and leadership. Employees of generation Y wants to succeed in harder and more meaningful jobs and for this reason they give importance to the mission and values of the institution where they work in (Ng et al., 2010; 283). Members of this generation are talented in terms of solving problems in their working environment. In order to reach the goals specified, they virtue teamwork. They have a more cooperative nature compared to the elder generations (Zemke et al., 2013; 132). Members of generation Y rapidly want to reach the tools that would meet their needs. Besides, they want 
to establish relationships with different people and want people to respect them and their ideas (Raman et al., 2011; 144). This generation, which expects respect from people, always expects praise for accomplishments (Meier and Crocker, 2010; 69). Employees from generation $\mathrm{Y}$ has high career goals and expectations. Career goals and expectations are not limited to the awards they get and performance they exhibit $(\mathrm{Ng}$ et al., 2010; 282). Employees of generation Y do not want to work all day. They want spare time for themselves and they cherish having quality time (Wallace, 2007; 8). Generation Y, which gives importance to diversity, equality, and tolerance, is not willing to work in the same workplace for a long time (Morton, 2002).

\section{Fun At Work}

Fun at work is a topic that is investigated from the past until this time (Costea et al., 2005). Fun at work is associated with employees spending good time (Dandridge, 1986), represents the beliefs of employees towards the organization being in a good point and carrying out the factors that affect achievement of employees in an entertaining way. Accordingly, fun at workplace comprises entertaining activities that would provide pleasure (Ford et al., 2003, 22; Plester, 2009; 585). Lamm and Meeks (2009; 614) define fun at work to be social and interpersonal activities, which provide pleasure and satisfaction. Fun becomes an important part of the organizational life when it occurs in a way that improves cooperation and social relations (Bolton and Houlihan, 2009; 557). Importance of fun at work emerges mostly while trying to reach organizational goals (Choi et al., 2013; 413). Sports activities, celebrations, parties, competitions and shows in the workplace are perceived to be entertaining (Vijay and Vazirani, 2011; 24 - 25). Besides these, activities like company trips, picnics, dinner organizations, card games, celebrations also fall within the definition of fun at workplace (Karl and Peluchette, 2006, 137; Tews et al., 2013; 371).

It is presented in studies that fun at work increases motivation of the employees, teamwork, quality, productivity, creativity and customer satisfaction (Berg, 2001). Employees having fun in the workplace have less conflicts, better communication and greater sense of belonging (Chan, 2010; 721); fun at work cont- ributes in decrease of problems and improvement of healthy relations in the workplace. People working this way, joke with one another and therefore improve their social interactions (Romero and Cruthirds, 2006; 59). Employees, who are happy and satisfied with their workplace experience less stress, cooperate within the institution and work in a more creative way compared to the ones who are unhappy (Ford et al., 2003; 24). People who have fun while working in their workplace and who are pleased with this environment have less tendency to search for a new job (Moen et al., 2011).

Two factors are important for employees to have fun in the workplace. First one is the employee's intention; and the second one is managers' support towards fun at work. Hence, in order to have fun in the workplace, not only should expectations from managers emerge, but also employees have to take initiative towards that. Fun at work must not only be provided in specific departments but around the entire workplace (Scott, 2008). On the other hand, it is important that fun should occur in a controlled manner. Spending most of the time having fun, postponing the tasks and serving customers in a way that would affect their perception negatively can result in severe unwanted consequences (Newstrom, 2002; 8). At this point, managers should set up the limits that would please all parties and fulfill their responsibility to prevent negative consequences.

Employees' attitudes towards fun at the workplace are also closely related to their general beliefs of work and fun. Employees' attitudes towards fun are shaped depending on factors like socialization, work ethics and personal differences and therefore affect the levels of experienced fun (Aldag and Sherony, 2002; 10).

\section{Job Satisfaction}

Job satisfaction can be described as the positive attitude that employees generate towards their jobs. Employees generate attitudes about their jobs as a result of the characteristics of the job they are doing, the social status they gain from their position and experiences they gain in their work environment. If the benefits of, social status earned from and the structure of the job fits expectations of employees, job satisfaction emerges (Çelik, 2011; 8). Ciarniene 
et al. $(2010$; 978) define jobs satisfaction to be the satisfaction that employees acquire after the efforts they made; and they also present that employees with higher levels of job satisfaction generate a positive attitude towards their jobs. Saibou (2006; 777) stated that job satisfaction depends on the balance between difficulties experienced while doing the job and benefits earned after finishing it. Parvin and Kabir (2011; 113) argued factors that affect job satisfaction level to be the payment and benefit, fair promotion system inside the company, improved working conditions, leadership, and social relations. Chabalala (2006; 16 17), in addition to these factors, addressed job stress, job security, and communication technology. Duffy and Richard (2006; 549) examine job satisfaction under two categories; satisfaction from the work and satisfaction form the work environment. Satisfaction from the work is the satisfaction felt by employees while doing their duties. And the satisfaction originated from the work environment consists of factors such as; management, managers, colleagues, working conditions, and working hours.

Decrease in the commitment to the organization, increases the absence and occupational hazards (Azır1, 2011; 79). Employees, who are satisfied with the job they are doing, show their commitment to the institution by working more carefully and giving a quality service to customers (Yee et al., 2010; 110). Employees' satisfaction of their jobs is an important factor for overall work performance and increase in productivity (Patterson et al., 2004). Job satisfaction or dissatisfaction affects employees' performance, level of taking responsibility within the company, cooperation with peers, view towards the work and their turnover intention (Lan et al., 2012; 629). Employees with high satisfaction level like their jobs and account their workplace environment as "fair". People who are happy with their jobs can devote their time to work, can be more creative and responsible. For aforementioned reasons, managers intend and wish to constitute and increase their employees' job satisfaction (Bakotic, 2012; 54).

\section{Turnover intention}

Many researches that are conducted about employees leaving their jobs present that intend of leaving the organization is mostly related to job satisfaction
(Çekmecelioğlu, 2005; 84). Among various factors that affect the turnover intention, job satisfaction comes more into prominence (Randhawa, 2007; 150). Employers try to make their employees to be satisfied with their jobs through arranging workplace environment and making structure of the work more suitable and thus keeping them at their current position.

(Mbah and Ikemefuna, 2012; 275 - 276). Facilitating fun at work also increases morale and performance of the employees, and therefore, employees would not think of leaving their job (Pryor et al., 2010). Also, according to a study supporting this thought, employees, who exhibit a positive attitude towards fun at work and have fun in the workplace, do not prefer to leave their jobs (Karl et al., 2008; 77 - 78).

In addition, justice inside the organization, workload, resource adequacy, supervisory support and peer support and job satisfaction influence decision of employees about working for or leaving an institution (Chen et al., 2008; 278). Factors such as loss of seniority within the organization and disruption of personal relationships and loss of income also affect the decision of leaving a job. Employees who work under uncertainty, leave or think of leaving of their jobs (Vardaman et al., 2008; 1532). On the other hand, existence of alternative job opportunities is another factor that affects the employees' turnover intention and behavior (Gerhart, 1989; 3 - 4).

Resigning employees create a negative effect on the productivity of the institution; because when valuable employees leave, organizational performance is affected negatively. Institutions will have more chance to intervene for keeping valuable employees with analyzing prior reasons of resignations. In this way costs caused by those who leave can be reduced (Chang et al., 2013; 1 -2). As there is a cost caused by those who leave their jobs, people who have the intention to do so can also be accounted to have negative effects on the organization. In addition, this decision constitutes a price for those who leaves their jobs as well.

\section{Related Studies}

Subjects related to fun at work, job satisfaction, turnover intention are among subjects that draw attention of researchers and there are many studies held 
on these subjects. Another topic that draws attention of researchers is evaluating perspectives of employees from different age generations towards fun at work, job satisfaction and their turnover intention and also differences between points of view of generations towards these concepts.

Dermody (2002; 108 - 114) conducted a study that aims to list the reasons why employees prefer to work in a restaurant, and why these employees continue to work. According to the results of this study reasons why employees choose this specific restaurant to work and continue their jobs are found to be the work environment and atmosphere. It is manifested that employees desire a fun atmosphere at work, with the contributions of the managers, formation of such a working atmosphere is a necessity for keeping them at the job. It is emphasized that turnover intention of employees can be prevented through formation of an environment where employees can have fun and thus increasing their morale.

Karl and Peluchette (2006; 132 - 135), in a study that they conducted on 142 people who work in health institutions showed that attitude towards fun at work is slightly related to the experienced fun. Job satisfaction of employees who exhibit positive attitude towards fun at work would increase as well; on the other hand, fun at work is found to decrease the negative factors that affect job satisfaction. The study which is conducted by Inn and Ching (2010; $14-21)$ with 102 people who work in the railway operation in Hong Kong, which has a stressful work environment, showed that fun at work affects job satisfaction positively at a very high degree. And through this strong effect, attitude towards fun at work plays a moderator role. On the other hand, this study presents that activities and initiatives towards fun at work affect both employees' and organization's outputs positively since happy employees also have a higher productivity.

Alam and Mohammad (2010; 128 - 133) conducted a study to measure the effect of job satisfaction level on the turnover intention. This study was held in the health sector and data was collected from 153 nurses through questionnaires. As a result of the analysis, things that nurses are satisfied with are collated under six dimensions. These dimensions are; satisfaction with supervisor, job variety, closure, compensation, co-workers and human resource management policies. As a result of the study, it is determined that nurses with higher job satisfaction have a lower level of turnover intention. In Jou et al. (2013; 98 - 100) study conducted in Taiwan air traffic control with $189 \mathrm{emp}-$ loyees, where job satisfaction played the role of mediator in between job stress and turnover intention, it is determined that job satisfaction has a significant effect on the turnover intention. Garboua et al. (2001; 8 - 20), in their study conducted in the German socioeconomic panel with employees from the ages 25 to 40 , showed that employees compare their jobs with the job done at the same level in different companies and as a result of this comparison, if job satisfaction is higher compared to their equivalent, they would prefer to work in their current jobs.

Young et al. $(2013 ; 155$ - 165) in their study investigated the differences between generations in terms of job satisfaction in a campus recreational sports facility. Three generations; Baby Boomers, generation $\mathrm{X}$ and generation $\mathrm{Y}$ were examined. As a result of the study, differences in job satisfaction emerged in four distinct areas. These are; supervisory support, work conditions, work environment and benefits gained by the employee. When these four factors are considered, the most satisfied generation with their jobs is accounted to be the Baby Boomer generation. It was found to exist no statistically significant difference among generations $\mathrm{X}$ and $\mathrm{Y}$ in terms of job satisfaction. When examined from the perspective of work conditions, work environment and benefits gained by the employees, yet again there was no statistically significant difference among the generations $\mathrm{X}$ and $\mathrm{Y}$.

Tremblay et al. (2010; 416 - 420) concerning the turnover intention in the health sector, conducted a study with 1376 employees who work at a university hospital in Canada in order to investigate differences between generations. According to the results of the study, turnover intentions of generations $\mathrm{X}$ and $\mathrm{Y}$ are found to be more than of the Baby Boomer generation. Generations $\mathrm{X}$ and $\mathrm{Y}$, in order to advance in their careers, think of leaving the organization. And Baby Boomer generation mostly only thinks of leaving the organization when the retirement time comes. According to another result of this study; managers, in 
order to keep employees in their jobs, can and should present conditions that motivate them to continue their jobs by developing strategies specific to each generation's unique properties.

Yin-Fah et al. (2010; 60 - 62) conducted a study towards specifying the relationship between job stress, job satisfaction and turnover intention. As a result of the study, it is determined that employees who are not satisfied with their jobs tend to leave. And similarly, employees who experience job stress generally have lower job satisfaction, employees with high level of job stress tend to leave their jobs. In addition, it is found out that the turnover intention of generation $\mathrm{Y}$ employees is more than employees from other generations. Kowske et al. (2010) held a study that reflects the perspective of generations about job satisfaction and turnover intention. This study was held on 115 employees who participated in a panel in America. As a result of the study, generally, job satisfaction is most manifested in generation Y. Generation Y happened to be the one which is most satisfied with job security, recognition, and career development which are some of the elements towards the job. But compared to Baby Boomers and generation X, generation $Y$ reported similar levels of satisfaction with pay and benefits and work itself, and also showed similar turnover intention related to these elements. Moreover, without considering the differences between generations, it is determined that, employees who were not satisfied usually changed their jobs.

Choi et al. (2013; 417 - 421) conducted a study on 234 master students who work in the hospitality industry in United States of America. In this study, people who were born in between 1971 and 1981 is accepted to be generation Y. According to the results of the study, attitudes of these employed students towards fun at work are effective in their experienced fun. Fun at work also affects job satisfaction positively. Attitude of generation $\mathrm{Y}$ towards fun at work is found to be high. These students from generation $\mathrm{Y}$ experiencing fun in the workplace manifested their job satisfaction to increase.

Lamm and Meeks (2009; 619 - 628) researched the moderator effect of Baby Boomers, generation X and
$\mathrm{Y}$ in the relationship between fun at work and workplace outcomes (job satisfaction, task performance and organizational citizenship behavior). The research was conducted with 701 employees where 271 of them are from Millennium generation (generation Y), 310 from generation X and 120 from Baby Boomer generation. As a result of the study, it is concluded that, different generations have different attitudes towards fun at work. Employees from generation $\mathrm{Y}$ want to have more fun in the workplace and give more importance to fun at work. The attitude of Baby Boomer generation towards fun at work was found to be not negative but happened to be very close to zero. It is been observed that job satisfaction of Baby Boomer generation is more than of generation X. Relationship between fun at work and job satisfaction was stronger for Baby Boomers compared to generation X. Whereas, it was predicted that the relationship between workplace fun and job satisfaction would be stronger for generation X. On the other hand, it was presented that the relationship between fun at work and job satisfaction is stronger for generation $\mathrm{Y}$ compared to generation $\mathrm{X}$.

The study, which is about the effect of activities towards fun at work and support of the manager about this subject on turnover and performance, held by Tews et al. (2013; 373 - 378) is conducted with 195 restaurant waiters/waitresses who work in a restaurant chain in the United States of America. The average age of employees is 25,67 . As a result of the study, it is presented that activities towards fun at work registers a positive effect on employees' performance and this effect is even stronger on elder people. It is specified that manager's encouragement and support to have fun at work decreases turnover, and especially, this effect is stronger on the younger ones. However, according to the results, support of managers towards fun at work affects performance negatively, regardless of age.

\section{Objectives and Hypotheses}

This study was conducted in order to present attitudes towards fun at work, experienced fun, job satisfaction and turnover intention of people who were born in different periods (generations); to specify the relationships between attitudes towards fun at work, expe- 
rienced fun, job satisfaction and turnover intention; also determining differences between these variables from the point of generations in the direction of the relationships that take place in the studies explained above. We claim that attitude towards fun at work affects turnover intention negatively. Dermody (2002; 114) resulted that attitude towards fun at work negatively affected turnover intention. If employees have fun at work, their turnover intention should decrease. It is expected that attitude towards fun at work positively affects job satisfaction. In and Chang (2010; 20 - 21) and also Choi et al. $(2013 ; 419)$ resulted that attitude towards fun at work positively affects job satisfaction. Karl and Peluchette $(2006 ; 131)$ cited that attitude towards fun at work decreases factors affec- ting job satisfaction negatively. At third stage, we claim that job satisfaction decreases turnover intention. Alam and Mohammad (2010; 133 - 134) and also Jou et al. $(2013 ; 100)$ resulted that employees with higher job satisfaction have a lower level of turnover intention. Yin-Fah et al. $(2010 ; 60)$ cited that employees who are not satisfied with their jobs tend to leave their jobs. At last stage, we claim that attitude towards fun at work is correlated with experienced fun. Karl and Peluchette $(2006 ; 132)$ resulted that attitude towards fun at work is slightly related to the experienced fun. In this direction, the following hypotheses are constituted. Also, research model is constituted in accordance with purpose of research (Figure 1).

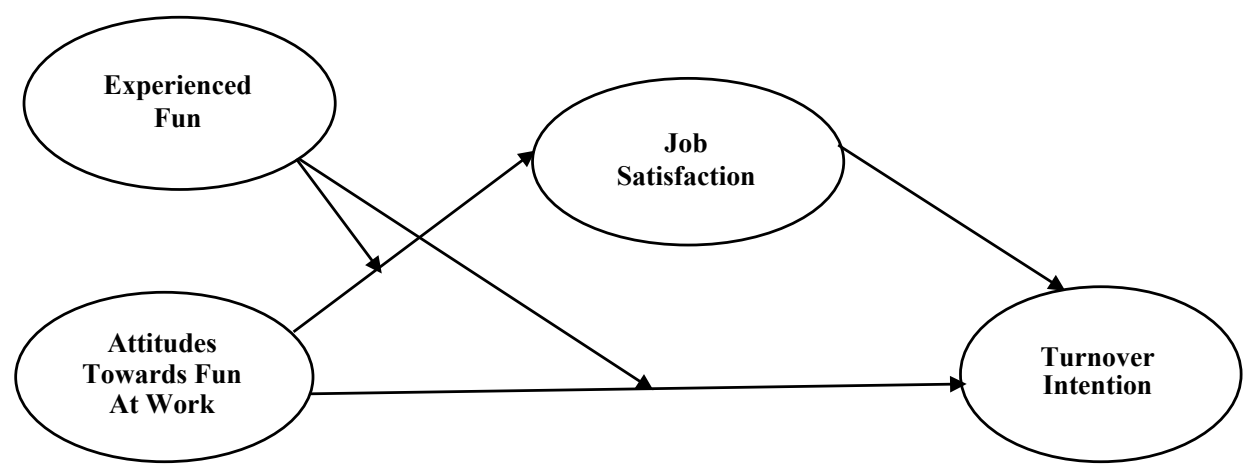

Figure 1. Research Model

$\mathbf{1 H}_{1:}$ There is a mediating role of job satisfaction in the effect of attitude towards fun at work on turnover intention.

$2 \mathbf{H}_{1}$. Experienced fun has a moderating role on the direct effects between attitude towards fun at work and turnover intention and the indirect effects formed through job satisfaction's mediating role.

$3 \mathrm{H}_{1:}$ From the point of generations there are differences in terms of (a) attitude towards fun at work, (b) experienced fun, (c) job satisfaction, (d) turnover intention.

\section{Methodology}

\section{Method and Profiles of Participants}

The study is conducted with 94 white-collar employees, who work in a production company, through questionnaire method. The research is conducted in a production company which produces over 50 various petrochemical outputs and has a big structure. Because of industry's structure and attributes, work environment at company is relatively static and only focuses on tasks. 
When demographical properties of participants are examined, it is observed that male participants are considerably more than female participants. The rate of female participants is $14 \%$ while male participants' rate is $86 \%$. It is seen that all of the participants have the level of education of undergraduate and graduate. The rate of people who got undergraduate degree is $52 \%$ while the rate of people who had a master's/ MBA degree is $45 \%$. And the rate of participants with associate degrees and doctorate education is approximately $2 \%$. With the total participants, Baby Boomer generation's rate is specified to be $12 \%$ while the rate of generation $\mathrm{X}$ is $48 \%$ and the rate of generation $\mathrm{Y}$ is $40 \%$.

\section{Scales Used}

Data in the research was acquired through a questionnaire, which is constituted benefiting from scales whose validity and reliability are tested in different studies in the literature. Attitude towards fun at work is measured benefiting from the ten-item scale that takes place in Aldag and Sherony's (2002) work, $\boldsymbol{e x}$ perienced fun from the seven-item-scale that Aldag and Sherony (2002) used, job satisfaction from the twenty-item Minnesota Job Satisfaction Scale (Spector, 1997) and turnover intention from the threeitem-scale that is used by Huang et al. (2007) in their study. Scales developed by Aldag and Sherony have been used at top index databases. Furthermore, there are a lot of studies which utilize from these scales. So these scales were used for measuring attitude towards fun at work and experienced fun. Job satisfaction scale developed by Spector is already known as Minnesota Job Satisfaction Scale. As it is very popular scale, it was used for measuring job satisfaction. Finally, it is thought that items of turnover intention scale developed by Huang et al. measures turnover intention reliably and accurately.

\section{Validity and Reliability Analysis}

Before getting to hypotheses tests, first validity and reliability analyses are done (Table 1 ). While factor analysis is held for validity, common variance is used with principal axis factoring. All KMO values are measured higher than the threshold and it is monitored that Bartlett's sphericity tests are significant. As a result of the factor analysis, it is observed that explained variance values for all factors are higher than 50\%. As common variance is worked with, error variant and unique variance is excluded. This method gives out the variance rate, which is explained according to principal components factor analysis that is based on total variant, but gives the opportunity of calculating with more valid results to the researcher. Since some statements that their shared variance (initial communality) is under $50 \%$, they were taken out of the analysis on the grounds of validity.

Table 1. Validity and Reliability Analyses

\begin{tabular}{|l|c|c|c|c|c|}
\hline & $\begin{array}{c}\text { Kaiser } \\
\text { Meyer } \\
\text { Olkin } \\
\text { KMO) }\end{array}$ & $\begin{array}{c}\text { Bartlett's } \\
\text { Test } \\
\text { (Sig.) }\end{array}$ & $\begin{array}{c}\text { Explained } \\
\text { Variance }\end{array}$ & Cronbach Alpha & Removed Items \\
\hline $\begin{array}{l}\text { Attitudes Towards Fun At } \\
\text { Work }\end{array}$ & 0,791 & 0,000 & $\% 52$ & 0,849 & 1 \\
\hline Experienced Fun & 0,873 & 0,000 & $\% 51$ & 0,862 & 1 \\
\hline Job Satisfaction & 0,879 & 0,000 & $\% 65$ & 0,932 & 1 \\
\hline Turnover Intention & 0,689 & 0,000 & $\% 65$ & 0,838 & - \\
\hline
\end{tabular}


Accordingly, 1 item from attitude towards fun at work variable, 1 item from experienced fun variable and 1 item from job satisfaction variable are extracted from the analysis. In addition, as a result of the reliability analysis held, it is seen that scales formed of statements directed towards all variables are high-degree reliable.

\section{Findings}

One sample t-test is conducted to test if the means of attitude towards fun at work, the experienced fun, job satisfaction and turnover intention are significantly different from five-point Likert scale's middle-cut point " 3 ". In order to comment on the means statistically, this test has a huge importance. The means higher than 3 and significantly different than 3 are specified to be significant-positive, lower than 3 are specified to be significant-negative (Table 2). Attitude towards fun at work mean has 3,44 mean and it states that attitude towards fun at work is positive. But experienced fun in the workplace (2.99) is significantly below the mean; this result states that experienced fun in the workplace is low. When table of the "means" is examined, it is observed that job satisfaction mean is 3,46 . Accordingly, it is possible to make the interpretation that answerers are generally satisfied with their jobs. Turnover intention is also significantly lower than the mean. From here, it is possible to comment that employees do not intent to leave their jobs.

\section{Table 2. Means of Variables}

\begin{tabular}{|l|c|l|}
\hline & Mean & $\begin{array}{c}\text { One Sample } \\
\text { t-test } \\
(3 \text { mean })\end{array}$ \\
\hline $\begin{array}{l}\text { Attitudes Towards Fun } \\
\text { at Work }\end{array}$ & 3,44 & Significant-positive \\
\hline Experienced Fun & 2,90 & Significant-negative \\
\hline Job Satisfaction & 3,46 & Significant-positive \\
\hline Turnover Intention & 2,55 & Significant-negative \\
\hline
\end{tabular}

In addition, other than the general means, means towards generations are also calculated (Table 3 ). It is observed that, with regards to attitude towards fun at work variable, the highest mean belongs to the generation Y. When looked with regards to variables, generation $\mathrm{X}$ and $\mathrm{Y}$ have a positive attitude towards fun at work. When looked with regards to job satisfaction, it is understood that the sample from all generations are satisfied with their jobs and at the same time they do not intend to leave their jobs.

Table 3. Means of Generation

\begin{tabular}{|l|c|c|c|c|}
\hline & $\begin{array}{c}\text { Attitudes } \\
\text { Towards Fun at } \\
\text { Work }\end{array}$ & $\begin{array}{c}\text { Experienced } \\
\text { Fun }\end{array}$ & $\begin{array}{c}\text { Job } \\
\text { Satisfaction }\end{array}$ & $\begin{array}{c}\text { Turnover } \\
\text { Intention }\end{array}$ \\
\hline $\begin{array}{l}1943-1960 \text { (Baby } \\
\text { Boomer) }\end{array}$ & 2,94 & $3,18^{*}$ & $4,08^{*}$ & $1,63^{*}$ \\
\hline $\begin{array}{l}1961-1981 \\
\text { (generation X) }\end{array}$ & $3,43^{*}$ & $2,76^{*}$ & $3,42^{*}$ & $2,60^{*}$ \\
\hline $\begin{array}{l}1982 \text { and later } \\
\text { (generation Y) }\end{array}$ & $3,58^{*}$ & 2,97 & $3,33^{*}$ & $2,75^{*}$ \\
\hline $\begin{array}{l}* \text { Mean values showing significant difference for one sample t-test (diversity from 3 } \\
\text { midpoint) }\end{array}$
\end{tabular}


Correlation analysis is conducted for the purpose of specifying the relations between attitude towards fun at work, experienced fun, job satisfaction, and turnover intention. In Table 4, there are correlation values between variables. When correlation table is exami- ned, there is no significant relationship between the variables of attitude towards fun at work and experienced fun statistically but in between all other variables, a significant relationship is found.

Table 4. Correlation Values Between Variables

\begin{tabular}{|l|c|c|c|}
\hline & $\begin{array}{c}\text { Attitudes } \\
\text { Towards Fun } \\
\text { At Work }\end{array}$ & Experienced Fun & Job Satisfaction \\
\hline $\begin{array}{l}\text { Attitudes Towards Fun at } \\
\text { Work }\end{array}$ & 1 & & \\
\hline Experienced Fun & $-0,016$ & 1 & 1 \\
\hline Job Satisfaction & $-0,321^{* *}$ & $0,461^{* *}$ & $-0,602^{* *}$ \\
\hline Turnover Intention & $0,325^{* *}$ & $-0,398^{* *}$ & \\
\hline$* *$ Significant \%99 confidence interval. Standardized values. ( $(3)$ & \\
\hline
\end{tabular}

In order to test the hypothesis established in form of "There is a mediating role of job satisfaction in the effect of attitude towards fun at work on turnover intention", hierarchical regression analysis and Baron and Kenny's (1986) four steps method are benefited from. When attitude towards fun at work is approached singly, it is seen that it has a positive effect $(b=0,507)$ on turnover intention.

According to the results of hierarchical regression analysis, we can talk about the positive indirect effect $(b=0,2791)$ of attitude towards fun at work on turnover intention by means of affecting job satisfaction
(Table 5). As desire towards fun at work increases, job satisfaction decreases $(b=-0,3414)$, and as a result of decreased jobs satisfaction, because of the negative relation $(b=0,-8176)$ in between them, turnover intention increases $\left(b_{\text {indirect }}=0,2791\right)$. In addition, when job satisfaction tool is approached as a mediator variable, the direct effect of attitude towards fun at work on turnover intention becomes statistically insignificant. This situation fulfills the requirement of full mediation. Under the circumstances, the first hypothesis is accepted. Explanatory level of the model is calculated to be $\% 38.1$, values about $\mathbf{R}^{2}$ are situated in Table 6 .

Table 5. Results of Hierarchical Regression Analysis

\begin{tabular}{|l|c|c|}
\hline & \multicolumn{2}{|c|}{ Turnover Intention } \\
\hline & Direct Effect & Indirect Effect \\
\hline Attitudes Towards Fun at Work & 0,2280 & $0,2791 *$ \\
\hline Job Satisfaction & $-0,8176^{*}$ & \\
\hline $\begin{array}{l}\text { Attitudes towards fun at work-job satisfaction } \mathrm{b}=-0,3414 \\
* \text { Significant } \mathbf{0 , 0 5} \text { confidence interval. }\end{array}$ \\
\hline
\end{tabular}

Table 6. Explanatory Level of The Model

\begin{tabular}{|c|c|c|c|c|}
\hline Standard Deviation & $\mathrm{p}$ & $\mathrm{Z}$ & $\mathrm{R}$ & $\mathrm{R}^{2}$ \\
\hline 0,979 & .0044 & 2,8496 & 0,6173 & 0,3810 \\
\hline
\end{tabular}


For the purpose of testing the second hypothesis that is formed as "experienced fun has a moderating role on the direct effects between attitude towards fun at work and turnover intention and the indirect effects formed through job satisfaction's mediating role", in order to introduce moderating role of experienced fun, in other words its moderated mediation effect; the conditional effect divided into percentiles is calculated benefiting from the method of bootstrap confidence intervals. As a result of the test, with the increase in the experienced fun, it is observed that job satisfaction's mediation effect increases - Standard value of the moderating variable is increased under controlled percentages (percentiles). Thus, the indirect effect of attitude towards fun at work on turnover intention increases gradually. Gradual increase values are located in Table 7.
Gradual increase in the standardized $(\mathrm{Z})$ values of experienced fun variable is examined (See Table 8). When the standard value of experienced fun reaches 0,1062 (its value in $50 \%$ confidence interval), the direct effect of attitude towards fun at work on turnover intention, which is calculated as part of hypothesis 1 and came out to be statistically insignificant, becomes significant. These values indicate the result that, turnover intention is increased as an increase in experienced fun escalates the attitude towards fun at work. According to the results emerged, the experienced fun has moderating roles on the direct effects in between attitude towards fun at work and turnover intention and indirect effect that are formed through job satisfaction. Therefore, the second hypothesis is accepted.

Table 7. Moderating Effect of Experienced Fun On The Indirect Effect of Attitude Towards Fun At Work On Turnover Intention

\begin{tabular}{|c|c|c|c|}
\hline $\begin{array}{c}\text { Dependent } \\
\text { Variable }\end{array}$ & \multicolumn{2}{|c|}{ Turnover Intention } & $\begin{array}{c}\text { Experienced Fun } \\
\text { (Moderator) }\end{array}$ \\
\hline Mediator Variable & Direct Effect & Confidence Interval & "Z" value \\
\hline \multirow{4}{*}{ Job Satisfaction } & $0,1857^{* *}$ & $\% 10$ & $-0,8938$ \\
\cline { 2 - 4 } & $0,2113^{* *}$ & $\% 25$ & $-0,3938$ \\
\cline { 2 - 4 } & $0,2369^{* *}$ & $\% 50$ & 0,1062 \\
\cline { 2 - 4 } & $0,2540^{* *}$ & $\% 75$ & 0,4395 \\
\cline { 2 - 4 } & $0,2796^{* *}$ & $\% 90$ & 0,9395 \\
\hline \multirow{2}{*}{$\begin{array}{l}\text { Independent Variable: Attitudes Towards Fun at Work } \\
\text { *LCCI and ULCI values are at positive interval. }\end{array}$} \\
LLCI = lower level of the bias-corrected 95\% bootstrap confidence interval. \\
ULCI = upper level of the bias-corrected 95\% bootstrap confidence interval. \\
\hline
\end{tabular}

Table 8. Moderating Effect of Experienced Fun on The Direct Effect of Attitude Towards Fun at Work On Turnover Intention

\begin{tabular}{|c|c|c|c|}
\hline Dependent Variable & \multicolumn{2}{|c|}{ Turnover Intention } & Experienced Fun \\
\hline Independent Variable & Direct Effect & Confidence Interval & "Z" values \\
\hline \multirow{4}{*}{$\begin{array}{c}\text { Attitudes Towards Fun At } \\
\text { Work }\end{array}$} & 0,0937 & $\% 10$ & $-0,8938$ \\
\cline { 2 - 4 } & 0,2275 & $\% 25$ & $-0,3938$ \\
\cline { 2 - 4 } & $0,3613^{* *}$ & $\% 50$ & 0,1062 \\
\cline { 2 - 4 } & $0,4504^{* *}$ & $\% 75$ & 0,4395 \\
\cline { 2 - 4 } & $0,5842^{* *}$ & $\% 90$ & 0,9395 \\
\hline \multirow{2}{*}{$\begin{array}{l}\text { **LCI and ULCI values are at positive interval. } \\
\text { LLCI } \text { lower level of the bias-corrected } 95 \% \text { bootstrap confidence interval. } \\
\text { ULCI = upper level of the bias-corrected 95\% bootstrap confidence interval. }\end{array}$} \\
\hline
\end{tabular}


The model's $\mathbf{R}^{2}$, which presents the moderated mediation effect, is calculated to be 0,4234 (Table 9). In brief, explanatory level of model in terms of the change in variance is about $42 \%$. This value is higher compa- red to the model which experienced fun does not take place in as a moderator variable and it represents an increase of $4 \%$ compared to the former model.

Table 9. Explanatory Level of The Model Which Presents the Moderated Mediation Effect

\begin{tabular}{|c|c|c|c|c|}
\hline $\begin{array}{c}\text { Dependent Variable: } \\
\text { Turnover Intention }\end{array}$ & $\mathbf{p}$ & $\mathbf{F}$ & $\mathbf{R}$ & $\mathbf{R}^{2}$ \\
\hline $\begin{array}{c}\text { Independent Variables: } \\
\text { - Job Satisfaction } \\
\text { - Attitudes towards }\end{array}$ & & & & \\
$\quad \begin{array}{l}\text { Fun at Work } \\
\text { - Experienced Fun }\end{array}$ & .000 & 15,9722 & 0,6507 & 0,4234 \\
- İnt_1 & & & & \\
- İnt22 & & & & \\
\hline & İnt_1; Int 2= Attitudes towards fun at work *xperienced fun \\
\hline
\end{tabular}

On the purpose of testing the third hypothesis formed as "from the point of generations there are differences in terms of (a) attitude towards fun at work, (b) experienced fun, (c) job satisfaction, (d) turnover intention", difference test is applied to sample groups that consist of generation X and Y (Sample size for Baby Boomers generation was low and therefore could not be included in the variance analyses. For this reason, only the differences among $\mathrm{X}$ and $\mathrm{Y}$ generations were taken into consideration. Nevertheless; X, $\mathrm{Y}$ and Baby Boomers tryouts gave out no difference). As a result of the ANOVA test applied no statistically significant difference between generation $\mathrm{X}$ and $\mathrm{Y}$ from the aspect of attitude towards fun at work, job satisfaction and turnover intention was found. Under the circumstances, third hypothesis is rejected.

\section{Conclusion}

At the present time employees want to have fun in the workplace and because of this, businesses, now, try to fulfill the expectation of employees by constituting more enjoyable workplace. Especially generation Y demands to have fun activities in the workplace and to work in a flexible and comfortable way. But when employees look fun at work positively, the nature and meaning of the job they are doing may disappear. And fun at work shows how often and to what extent employees have fun in the workplace. As attitude towards fun at work increases, and in a workpla- ce where experienced fun also gets higher with this increase; employees focus on spending quality time rather than the job itself. Thus, they do not apprehend the meaning of the job they are doing and eventually satisfaction they get from the job may be lower. This situation may cause employees to think of leaving their jobs. Consequently, institutions that evaluate attitudes of employees towards fun at work well, and that succeeds in keeping the experienced fun in the workplaces in an optimum level, may keep employees longer in the workplace. This result supports some researches mentioned in the literature (Dermody, 2002; Karl and Peluchette, 2006; In and Ching, 2010). Ignoring employee's desires and needs completely or largely while trying to adjust this level of experienced fun, can lower employees' job satisfaction and increase their turnover intention. Consequently, in order to employees to have fun and to fulfill their responsibilities when the work time comes, it is obvious that the balance between fun and severity/responsibility in the workplace must be established well.

The average values acquired in the direction of the answers, which are evaluated as part of the research, given by the participants to the survey questions, show that participants are satisfied with their jobs and do not intend to leave their jobs. And their attitude towards fun at work is measured to be higher than experienced fun. This situation shows that they have fun less than they expect. Attitude towards fun 
at work has a direct effect on employees' turnover intention and partial mediating role of job satisfaction on this effect is monitored. When employees exhibit a positive attitude towards fun at work, job satisfaction decreases and employees with low job satisfaction think more of leaving their jobs. The increase in the experienced fun has a raising role on the direct effect between attitude towards fun at work and turnover intention and indirect effect of attitude towards fun at work that emerges through the mediating role of job satisfaction. Accordingly, it is possible to mention the moderating role of experienced fun in direct and indirect relations between variables. As the present experienced fun increases in the workplace, as a result of the effect of attitude towards fun at work on turnover intention get stronger; employees can think more of leaving their jobs.

It is observed that there is no significant difference between generation $\mathrm{X}$ and $\mathrm{Y}$ in terms of attitude towards fun at work, experienced fun, job satisfaction and turnover intention. These results present that for the sample discussed within the research, generation $\mathrm{X}$ employees give as much as importance to fun as generation $\mathrm{Y}$ does. This result presented also supports some researches mentioned in the literature (Gursoy et al., 2008; Lamm and Meeks, 2009).

As employees have expectations towards fun at work without generation distinction, and may think of leaving their jobs when these expectations of them are not met, organizations are required to fulfill these expectations in a level in order to have their continuity, carry out their activities effectively and efficiently. In order to design fun workplaces, without considering the generations, all employees' opinions must be got; management must act in this direction. If the workplace provides enough fun opportunity and this situation does not prevent the seriousness of carrying out the necessities of jobs, if employees and management redressed the necessary balance for this topic, employees perceive their jobs to be pleasant and depending on this factor, do not think of leaving their jobs.

\section{Suggestions For Future Studies}

This study can be extended by following researches to constitute a new model for fun at work by adding new variables. Variables like manager support, creativity and happiness can be added to the model and different and extensive results can be obtained. Moreover, negative influence of attitude towards fun at work on job satisfaction have been revealed by this study. So future research may focus relation between attitude towards fun at work and job satisfaction with few additional variables measuring the "meaning/sense" of job as control variables. Our research has very limited application area and therefore results are limited to just one industry; so, a broader sense of industries can contribute to the model and as well as our extraordinary result showing a negative correlation among fun at work and job satisfaction. The possible reasons of this result are argued throughout the conclusion, so any research concerning this relation and its antecedents creates new opportunities concerning the "meaning/sense" of working and balance between work and fun.

There are certain limitations to this research such as it was applied to only one company and a relatively small sized sample makes the research's conclusion to be only bound to one case. Therefore, for the future researches, it is suggested that this case research to be extended to industry-wide scale. Larger sample will offer new probabilities also taking aforementioned suggestions for the model into account. 


\section{References}

Alam, M. M., Mohammad, J. F. (2010). Level of Job Satisfaction and Intent To Leave Among Malaysian Nurses. Business Intelligence Journal, 3 (1), 123-137.

Aldag, R. J., Sherony, K. (2002). Fun At Work: Measurement and Correlates. American Psychological Society, 1-29.

Ayhün, S. E. (2013). Kuşaklar Arasındaki Farklllıklar ve Örgütsel Yansımaları. Ekonomi ve Yönetim Araştırmaları Dergisi, 2 (1), 93-112.

Azır1, B. (2011). Job Satisfaction: A Literature Review. Management Research and Practice, 3 (4), 77-86.

Bakotic, D. (2012). Job Satisfaction of Knowledge Workers In Croatian Companies. The Journal of International Management Studies, 7 (2), 53-60.

Berg, D. H. (2001). The Power of A Playful Spirit At Work. The Journal For Quality \& Participation, 24 (2), 57-62.

Bolton, S. C., Houlihan, M. (2009). Are We Having Fun Yet? A Consideration of Workplace Fun and Engagement. Employee Relations, 31 (6), 556-568.

Cairncross, G., Buultjens, J. (2007). Generation Y and Work In The Tourism and Hospitality Industry: Problem? What Problem?. Centre For Enterprise Development and Research, 9, 1-21.

Cennamo, L., Gardner, D. (2008). Generational Differences In Work Values, Outcomes and Person - Organisation Values Fit. Journal of Managerial Psychology, 23 (8), 891-906.

Chabalala, M. D. (2006). Evaluating The Level of Job Satisfaction of Financial Inspectors In The Limpopo Inspectorate Division. Division of Economic and Management Sciences Unisa, 1-48.
Chan, S. C. H. (2010). Does Workplace Fun Matter? Developing A Useable Typology of Workplace Fun In A Qualitative Study. International Journal of Hospitality Management, 29, 720-728.

Chang, W. J. A., Wang, Y. S., Huang, T. C. (2013). Work Design-Related Antecedents of Turnover Intention: A Multilevel Approach. Human Resource Management, 52 (1), 1-26.

Chen, H. C., Chu, C. I., Wang, Y. H., Lin, L. C. (2008). Turnover Factors Revisited: A Longitudinal Study of Taiwan - Based Staff Nurses. International Journal of Nursing Studies, 45, 277-285.

Choi, Y. G., Kwon, J., Kim, W. (2013). Effects of Attitudes vs Experience of Workplace Fun On Employee Behaviors: Focused On Generation Y In The Hospitality Industry. International Journal of Contemporary Hospitality Management, 25 (3), 410-427.

Ciarniene, R., Kumpikaite, V., Vienazindiene, M. (2010). Expectations and Job Satisfaction: Theoretical and Empirical Approach. 6th International Scientific Conference, Business and Management, Vilnius, 978-984.

Costea, B., Crump, N., Holm, J. (2005). Dionysus at Work? The Ethos of Play and the Ethos of Management. Culture and Organization, 11 (2), 139-151.

Crampton, S. M., Hodge, J. W. (2009). Generation Y: Unchartered Territory. Journal of Business \& Economics Research, 7 (4), 1-6.

Çekmecelioğlu, H. G. (2005). Örgüt İkliminin İş Tatmini ve İşten Ayrılma Niyeti Üzerindeki Etkisi: Bir Araştırma. Dokuz Eylül Üniversitesi Sosyal Bilimler Enstitüsü Dergisi, 9 (1), 79-97. 
Çelik, M. (2011). A Theoretical Approach To The Job Satisfaction. Polish Journal of Management Studies, 4, 7-15.

Dandridge, T.C. (1986). Ceremony As An Integration of Work and Play. Organization Studies, 7 (2), 159170.

Deal, J. J., Altman, D. G., Rogelberg, S. G. (2010). Millenials At Work: What We Know and What We Need To Do (If Anything). J Bus Psychol, 25, 191199.

Dermody, M. B. (2002). Recruitment and Retention Practices In Independent and Chain Restaurants. International Journal of Hospitality \& Tourism Administration, 3 (1), 107 -117.

Duffy, R. D., Richard, G. V. (2006). Physician Job Satisfaction Across Six Major Specialties. Journal of Vocational Behavior, 68, 548-559.

Ford, R. C., McLaughlin, F. S., Newstorm, J. W. (2003). Questions and Answers About Fun At Work. Human Resource Planning, 26 (4), 18-33.

Garboua, L. L., Montmarquette, C., Simonnet, C. (2001). Job Satisfaction and Quits: Theory and Evidence From The German Socioeconomic Panel. Centre Interuniversitaire de Recherche en Analyse des Organisations, Montreal, 1-29.

Gerhart, B. A. (1989). Voluntary Turnover and Alternative Job Opportunities. Center For Advanced Human Resource Studies (CAHRS), 1-39.

Gursoy, D., Maier, T. A., Chi, C. G. (2008). Generational Differences: An Examination of Work Values and Generational Gaps In The Hospitality Workforce. International Journal of Hospitality Management, 27, 448-458.

Huang, T. C., Lawler, J., Lei, C. Y. (2007). The Effects of Quality of Work Life On Commitment and Turnover Intention. Social Behavior and Personality, 35 (6), 735-750.
In, C. Y., Ching, Y. H. (2010). Workplace Fun and Job Satisfaction: The Moderating Effects of Attitudes Toward Fun. Major In Human Resources Management, 1-31.

Jou, R. C., Kuo, C. W., Tang, M. L. (2013). A Study of Job Stress and Turnover Tendency Among Air Traffic Controllers: The Mediating Effects of Job Satisfaction. Transportation Research Part, 57, 95-104.

Karl, K. A., Peluchette, J. (2006) Does Workplace Fun Buffer The Impact of Emotional Exhaustion On Job Dissatisfaction?: A Study of Health Care Workers. Institute of Behavioral and Applied Management, 7 (2), 128-141.

Karl, K. A., Peluchette, J. V., Hall, L. M. (2008). Give Them Something To Smile About: A Marketing Strategy For Recruiting and Retaining Volunteers. Journal of Nonprofit \& Public Sector Marketing, 20 (1), 71-96.

Kian, T. S., Yusoff, W. F. W. (2012). Generation X and $Y$ and Their Work Motivation. Proceedings International Conference of Technology Management, Business and Entrepreneurship, 396-408.

Kowske, B. J., Rasch, R., Wiley, J. (2010). Millenials' (Lack of) Attitude Problem: An Empirical Examination of Generational Effects On Work Attitudes. J Bus School, 25, 265-279.

Lamm, E., Meeks, M. D. (2009). Workplace Fun: The Moderating Effects of Generational Differences. Employee Relations, 31 (6), 613-631.

Lan, G., Okechuku, C., Zhang, H. (2012). Impact of Job Satisfaction and Personal Values On The Work Orientation of Chinese Accounting Practitioners. J Bus Ethics, 112, 627-640.

Levickaite, R. (2010). Generations X,Y, Z: How Social Networks Form The Concept of The World Without Borders (The Case of Lithuania). LIMES, 3 (2), 170-183. 
Macunovich, D. J. (2000). The Baby Boomers. Macmillan Encyclopedia of Aging, 1-13.

Mbah, S. E., Ikemefuna, C. O. (2012). Job Satisfaction and Employees' Turnover Intentions In Total Nigeria Plc. In Lagos State. International Journal of $\mathrm{Hu}$ manities and Social Science, 2 (14), 275-287.

Meier, J., Crocker, M. (2010). Generation Y In The Workforce: Manegarial Challenges. The Journal of Human Resource and Adult Learning, 6 (1), 68-78.

Moen, P., Kelly, E. L., Hill, R. (2011). Does Enhancing Work - Time Control and Flexibility Reduce Turnover? A Naturally Ocuuring Experiment. Social Problems, 58 (1), 69-98.

Montana, P. J., Petit, F. (2008). Motivating Generation $\mathrm{X}$ and Y On The Job and Preparing Z. Global Journal of Business Research, 2 (2), 139-148.

Morton, L. P. (2002). Targeting Generation Y. Public Relations Quarterly, 47 (2), 46-52.

Myers, K. K., Sadaghiani, K. (2010). Millenials In The Workplace: A Communication Perspective On Millennials' Organizational Relationship and Performance. J Bus Psychol, 25, 225-238.

Newstorm, J. W. (2002). Making Work Fun: An Important Role For Managers. SAM Advanced Management Journal, 67 (1), 4-8.

Ng, E. S. W., Schweitzer, L., Lyons, S. T. (2010). New Generation, Great Expectations: A Field Study of The Millennial Generation. J Bus Psychol, 25, 281 $-292$.

Oppel, W. (2007). Generational Diversity: The Future of The American Workforce. Leadership Advance Online, 9, 1-3.

Parvin, M. M., Kabir, M. N. (2011). Factors Affecting Employee Job Satisfaction of Pharmaceutical Sector. Australian Journal of Business and Management Research, 1 (9), 113-123.
Patterson, M., Warr, P., West, M. (2004). Organizational Climate and Company Productivity: The Role of Employee Affect and Employee Level. Journal of Occupational and Organizational Psychology, 77, 193-216.

Plester, B. (2009). Crossing The Line: Boundaries of Workplace Humour and Fun. Employee Relations, 31 (6), 584-599.

Pryor, M. G., Singleton, L. P., Taneja, S., Humphreys, J. H. (2010). Workplace Fun and Its Correlates: A Conceptual Inquiry. International Journal of Management, 27 (2), 294-302.

Raman, G., Ramendran, C., Beleya, Prashanth., Nodeson, S., Arokiasamy, L. (2011). Generation Y In Institution of Higher Learning. International Journal of Economics and Business Modeling, 2 (2), 142148.

Randhawa, G. (2007). Relationship Between Job Satisfaction and Turnover Intentions: An Empirical Analysis. Indian Management Studies Journal, 11, 149-159.

Reeves, T. C., Oh, E. (2007). Generational Differences. J.M. Spector., M.D. Merrill., J. van Merrienboer., M.P. Driscoll. (Eds.), Handbook of Research On Educational Communications and Technology (s.295-303). New York: Springer.

Romero, E. J., Cruthirds, K. W. (2006). The Use of Humor In The Workplace. Academy of Management Perspectives, 20 (2), 58-69.

Saibou, H. (2006). Employee Job Satisfaction In Public Sector: A Study Based On The Case of Niger. Proceedings of The 7th International Conference On Innovation \& Management, 777-780.

Sayers, R. (2007). The Right Staff From X To Y: Generational Change and Professional Development In Future Academic Libraries. Library Management, 28 (8), 474 - 487. 
Scott, G. G. (2008). Make Work More Fun For Everyone, 101 Ways To Add Fun To Your Work Every Day. American Management Association International, 1-232.

Spector, P. E. (1997). Job Satisfaction: Application, Assessment, Causes, and Consequences. California: SAGE Publications.

Strauss, W., Howe, N. (1991). Generations: The History of America's Future, 1584 to 2069. New York: William Morrow and Company, 7 - 538.

Sudheimer, E. E. (2009). Appreciating Both Sides of The Generation Gap: Baby Boomer and Generation X Nurses Working Together. Nursing Forum, 44 (1), 5-63.

Susaeta, L., Pin, J. R., Idrovo, S., Belizon, M. J., Espejo, A., Gallifa, A., Aguirre, M., Pedrozo, E. A. (2013). Generation or Culture? Work Attitude Drivers: An Analysis In Latin America and Iberian Countries. Cross Cultural Management, 20 (3), 321-360.

Tews, M. J., Michel, J. W., Stafford, K. (2013). Does Fun Pay? The Impact of Workplace Fun On Employee Turnover and Performance. Cornell Hospitality Quarterly, 54 (4), 370-381.

Tolbize, A. (2008). Generational Differences In The Workplace. Research and Training Center On Community Living, 1-21.

Tremblay, M. L., Paquet, M., Duchesne, M. A., Santo, A., Gavrancic, A., Courcy, F., Gagnon, S. (2010). Retaining Nurses and Other Hospital Workers: An Intergenerational Perspective of The Work Climate. Journal of Nursing Scholarship, 42 (4), 414-422.
Vardaman, J. M., Allen, D. G., Renn, R. W., Moffitt, K. R. (2008). Should I Stay or Should I Go? The Role of Risk In Employee Turnover Decisions. Human Relations, 61 (11), 1531-1563.

Vijay, M., Vaziarni, V. (2011). Emerging Paradigm Fun in Workplace to Alleviate Stress. SIES Journal of Management, 7 (2), 24-30.

Wallace, K. (2007). Understanding and Managing Generation Y. Engineering Management Field Project, Faculty of The Graduate School of The University of Kansas, 1-33.

Yee, R. W. Y., Yeung, A. C. L., Cheng, T. C. E. (2010). An Empirical Study of Employee Loyalty, Service Quality and Firm Performance In The Service Industry. Int. J. Production Economics, 124, 109-120.

Yin-Fah, B. C., Foon, Y. S., Leong, L. C., Osman, S. (2010). An Exploratory Study On Turnover Intention Among Private Sector Employees. International Journal of Business and Management, 5 (8), 57-64.

Young, S. J., Sturts, J. R., Ross, C. M., Kim, K. T. (2013). Generational Differences and Job Satisfaction In Leisure Services. Managing Leisure, 18 (2), 152170.

Zemke, R., Raines, C., \& Filipczak, B. (2013). Generations At Work: Managing The Clash of Boomers, Gen Xers and Gen Yers In The Workplace, New York: AMACOM, 1 - 312. 